\title{
Section IX: Military Objectives by Nature
}

\begin{abstract}
Rule 77
"Military objectives", as far as objects are concerned, are those objects which by their nature, location, purpose or use, make an effective contribution to military action and whose total or partial destruction, capture or neutralization, in the circumstances ruling at the time, offers a definite military advantage.
\end{abstract}

\section{Commentary}

1. The definition is based on Article 52 (2) of AP/I.

2. Four critical terms in the definition are "nature", "location", "purpose" and "use". This Section applies mainly to military objectives by "nature". The extent of application of the category of military objectives by "nature" is not universally agreed upon. In particular, there is disagreement on whether military objectives by "nature" constitute an absolute or relative category. Rules 78 through 84 reflect the consensus reached by the Group of Experts.

3. The definition of military objectives is confined to objects. Human beings are not military objectives for the purpose of this particular definition, but may be lawful targets as combatants or civilians directly participating in hostilities.

4. Animals can be military objectives. An example could be a mule carrying military supplies. However, animals must not be made the object of attack unless required by military necessity, i.e., they constitute military objectives.

\section{Rule 78}

(a) An object can simultaneously fall within more than one of the "nature", "location", "purpose" and "use" classifications.

(b) In particular, the distinction between "nature" and "use" is that if an object qualifies as a military objective by nature it remains so classified irrespective of its current use. A military objective by "nature" can be 
attacked independently of its present "use", while a military objective by "use" can be attacked only if it is actually used for military purposes.

\section{Commentary}

1. The four key terms "nature", "location", "purpose" and "use" convey different meanings, but are nevertheless interlinked. Any one classification, or combination thereof, can serve as the basis for satisfying the test of whether an object is a military objective.

2. Generally speaking, a military objective by nature can be attacked at all times. However, there are obvious exceptions. For example, an obsolete tank, aircraft, or warship_-presented for display in a museum or elsewhere-would be exempted from attack. See also Rule 79.

3. Every civilian object can become a military objective by use, cf. Article 52(2) of AP/I.

4. An example is that of an art museum which-owing to its status as cultural property-does not constitute a military objective by nature. Nevertheless it can become a military objective by use if the enemy establishes, e.g., a command post there.

5. In the past broadcasting and TV stations were regarded as military objectives by nature. This view is today largely outmoded. In the past, such facilities were in most countries under centralized control and instrumental in passing information from the Government to the general public, including mobilisation orders. Today, broadcasting or equivalent functions take place from a multitude of studios and via the Internet and cell-phone networks in addition to traditional means. Broadcasting and TV stations will, however, in many situations be military objectives by use. ${ }^{1}$

6. As for military objectives by use in Outer Space, see Rule 10.

7. With regard to military objectives in cyberspace, see Rule 26.

\section{Rule 79}

The classification of an object as a military objective by "nature" is not altered only because it is in disuse or under repair, unless its fundamental character has changed.

\section{Commentary}

1. Even when not in use, such objects always constitute lawful targets during armed conflict. For example, an abandoned tank is still a military objective by nature, if it is capable of making an effective contribution to military action (e.g., it can be repaired/re-manned and used consistent with its nature). See also comment 2 to Rule 78.

\footnotetext{
${ }^{1}$ Note e.g. ICTY, Final Report to the Prosecutor by the Committee Established to Review the NATO Bombing Campaign Against the Federal Republic of Yugoslavia, paras. 71-79 (13 June 2000).
} 
2. However, some objects cease to be military objectives by nature, for example, when an object that was once military equipment is turned into a museum piece, its nature has changed and it may no longer be a military objective. In this regard, see chapter "Section XV: Cultural Property" on cultural property.

3. The principles of proportionality and of precautions in attack will apply notwithstanding the classification of an object as a military objective by nature. It should be recalled that (see Rule 78a) the fact that an object is a military objective by nature does not exclude the possibility that it can also be classified as a military objective by location, purpose or use.

\section{Rule 80}

(a) An object qualifying as a military objective by "nature" can be either movable or immovable.

\section{Commentary}

1. In order to qualify as a military objective by "nature", the object in question must have an inherent characteristic or attribute that contributes effectively to military action.

2. Objects under Rule 80 are typically designed and produced in order to be used for military purposes. They can be either movable or immovable.

(b) Examples of movable military objectives by "nature" include military aircraft (other than medical aircraft); tanks and armoured personnel carriers (APCs) (other than medical transport); missiles and other weapons; military equipment; warships; UMS operated by the armed forces; military satellites; and mobile military ground stations.

\section{Commentary}

1. Rule 80 (b) is based on the AMW Manual Rule 22 (a). ${ }^{2}$

2. See Rules 52 and 54 on UMS.

3. See Rule 9 on military satellites.

4. The list of movable military objectives provided here is not exhaustive and is limited to the most obvious examples.

5. Military medical aircraft are entitled to certain protections from being made the object of attack. Nevertheless, medical aircraft are not civilian objects.

(c) Examples of immovable military objectives by "nature" include military fortifications, facilities and depots; military ports and airfields; missile silos; military satellite communications facilities; armaments factories; and Ministries of Defence.

\footnotetext{
${ }^{2}$ See also, DoD Law of War Manual, chapter “Section II: Cyber Operations”, fn. 4, Section 6.6.1.1.
} 


\section{Commentary}

1. Ministries of Defence are military objectives even if such Ministries are staffed in part by civilians. Of course, to the extent that a Ministry of Defence has physically separate non-defence departments, as in the case of the Swiss Federal Department of Defence, Civil Protection and Sport (DDPS), its facilities devoted exclusively to such civilian functions are not military objectives by nature. ${ }^{3}$

2. The list of immovable military objectives provided here is not exhaustive and is limited to the most obvious examples.

\section{Rule 81}

Military Command, Control and Communications centres $\left(\mathrm{C}^{\mathbf{3}}\right)$ are military objectives by "nature", whether movable or immovable.

\section{Commentary}

1. The distinction between movable and immovable military objectives by "nature" does not apply to military $\mathrm{C}^{3}$ because they could be either the one or the other.

2. Needless to say, $\mathrm{C}^{3}$ objects are of critical importance for all military operations and their attack would likely always be prioritized by the enemy.

\section{Rule 82}

Computers that are components of weapons, weapon systems or other military systems (such as military radar stations or military Outer Space systems) are military objectives by "nature".

\section{Commentary}

1. For the purposes of this Manual, a computer is considered a component of a weapon, weapon system or other military system if it is designed from the outset or programmed specifically to play an essential role in the functioning of such weapons or systems. It can be an integral part of a weapon, a platform, a weapon system, a C3 system, etc.

2. Military computers can be either movable or immovable.

3. Computers that are military objectives by "nature" are categorically recognized as such regardless of their current use. Conversely, computers that are normally dedicated to civilian purposes may become military objectives by virtue of their actual use, e.g., in support of military action.

4. Military computers can be integral parts of a cyber infrastructure or operate on a stand-alone basis.

\footnotetext{
${ }^{3}$ See also, DoD law of War Manual, Section 5.6.4.
} 
5. Military computers can be attacked by cyber, kinetic or electronic means. They can be destroyed or made to malfunction in a way advantageous to the enemy.

6. When military computers that are connected to the Internet are attacked, the expected damage or destruction to systems connected to the Internet that are not military objectives must be kept in mind.

\section{Rule 83}

In addition to the items listed in Rules 80 through 82, which are military objectives by nature, objects that will presumptively qualify as military objectives by "nature" include, but are not limited to:

\section{Commentary}

1. Rule 83 is based on the concept that, whereas some objects constitute military objectives by "nature" in all circumstances (see Rule 80-82) there are other objects that may be presumed to be military objectives by nature, but that presumption may be rebutted due to the particular circumstances prevailing at the time.

2. Although the Group of Experts determined that there was a rebuttable presumption that certain objects were military objectives by nature, they recognize that several States would prefer that the Rule be expressed in terms of "very likely" instead of "presumptively".

3. Accordingly, objects which will "presumptively" qualify as military objectives by nature will in most practical circumstances be lawful targets unless the concrete circumstances prevailing at the time indicate otherwise.

4. The distinction between a more and less absolute "nature" of military objectives is also reflected in Articles 22 and 23 of the AMW Manual.

5. This position - that there are objectives that are not military objectives by nature as an absolute matter but may necessarily be presumed to be such in the absence of circumstances to defeat that presumption-was adopted by the majority of the Group of Experts. However, there was a dissenting opinion.

6. Rule 83 deals with objects that are normally also made for civilian use, but where the potential for military use is so evident that it is more likely than not that they would make an effective contribution to military action in the near future.

7. Paragraphs (a) to (g) set forth examples of the application of this Rule. It must be noted, however, that not every example is necessarily regarded by all of the participating experts in the Group as constituting military objectives by nature.

(a) Main railway lines, main roads, bridges and tunnels;

\section{Commentary}

1. Branch railway lines are military objectives by "nature" if they connect places of military significance such as military bases, depots, weapon systems and munition factories and important airfields or harbours to the main railway network. 
2. Railway lines that predominantly serve suburban commuter traffic are not military objectives by "nature".

3. Main roads include highways but may also include secondary roads when such roads would clearly serve as back-up if highways are closed. However, urban streets and avenues would not presumptively qualify as military objectives by nature.

4. Bridges and tunnels are military objectives by "nature" when they are a part of main railway lines or main roads, but they can be military objectives by "nature" for other reasons as well.

(b) If of military importance, data lines, fibre-optic cables, telephone lines and telegraph lines;

\section{Commentary}

1. Electronic communications are vital for military command and control purposes. Communication lines built for civilian purposes are likely to be used by the military in lieu of or as back-up for dedicated military lines.

2. Supporting structures, such as switchboards, servers and micro-wave datalink facilities are included among the objects that are presumptively military objectives by nature.

\section{(c) Airports and airstrips of military significance;}

\section{Commentary}

1. Airports and airstrips are of military significance when they are likely to serve as dispersal fields if military air bases are threatened by attack, or for bringing in military supplies when military air bases are closed.

2. Such airports and airstrips need to have runways of a sufficient length to serve combat or transport aircraft.

3. It must be borne in mind that attacks on civilian airports and airstrips always bring into play consideration of precautions and application of the proportionality principle. $^{4}$

\section{(d) Harbours of military significance;}

\section{Commentary}

1. Deepwater ports that are connected to main railway lines and main roads are presumed to be military objectives by "nature".

2. Harbours that are predominantly used by coastal fisheries, and marinas for yachting are not presumed to be military objectives by "nature".

\footnotetext{
${ }^{4} \mathrm{AP} / \mathrm{I}$, see fn. 15 , Article 51(5)(b). The principle of proportionality is recited in para 1 of the Commentary to Rule 11 .
} 
(e) Electricity production facilities serving military needs, including power transmission facilities and equipment;

\section{Commentary}

1. Electricity is necessary for operating military bases and many weapon systems. When such military needs are (as is usually the case) provided for over the general electricity grid, the electricity production facilities and their transmission infrastructure are military objectives by "nature". See Rule 84.

2. If, however, military and civilian electricity needs are served by separate production facilities and networks, only those serving military needs are military objectives.

3. In most practical circumstances, even if military bases, radar and weapons systems etc., have their separate electricity generators, the general electricity grid will serve industry, harbours, and transportation and communications systems of military importance. In such situations, collateral damage to civilian and civilian objects must be considered under the principle of proportionality. ${ }^{5}$

4. It should also be kept in mind that the party subject to attack has a duty to take precautions against the effects of attacks. ${ }^{6}$ Such "passive precautions" could for instance include the installation of emergency generators at hospitals and other particularly vulnerable civilian institutions.

(f) Oil production facilities for use by the enemy or its co-belligerents, oil terminals, refineries, crude oil and refined products storage depots, and pipelines.

\section{Commentary}

1. Fuel, predominantly based on oil, is vital for military operations. Facilities for producing, importing, refining, storing and transporting oil for use by the enemy or its co-belligerents are therefore military objectives by "nature".

2. If oil is produced and transported for export, generating revenues to finance the war effort, the facilities fall in the category of war-sustaining industries. The lawfulness of attacking such industries, as well as transportation to facilitate export, is contested. See also chapter "Section XI: Destruction of Property" Rule 101.

(g) Outer space systems and assets belonging to the armed forces.

\section{Commentary}

1. See Rule 9.

\footnotetext{
${ }^{5} \mathrm{AP} / \mathrm{I}$, ibid, Article 51(5)(b). The principle of proportionality is recited in para 1 of the Commentary to Rule 11.

${ }^{6} \mathrm{AP} / \mathrm{I}$, ibid, Article 58.
} 


\section{Rule 84}

The status of a military objective by "nature" is not altered, even if it is also used for civilian purposes.

\section{Commentary}

1. So-called dual-use objects will always constitute lawful military objectives in light of the fact that one component of the duality involves an effective contribution to the military effort.

2. Again, the principle of proportionality must be applied even when the object under attack is a military objective by nature.

\section{Rule 85}

Attacks that treat as a single object of attack a number of clearly separated and distinct lawful targets located in a city, town, village or area containing a similar concentration of civilians or civilian objects, are considered indiscriminate and are prohibited.

\section{Commentary}

1. This Rule is not restricted to military objectives by "nature".

2. Rule 85 is based on Article 51(5)(a) of AP/I which is reflective of customary international law.

3. Rule 85 is derived from the acute need to cope with the problem of "target area" bombing that arose in WWII. The text seriously limits the possibilities in which clusters of military objectives may be attacked as if they were a single lawful target. On the other hand, it does not deny the possibility that a number of lawful targets, which are not clearly separated and distinct, may be treated as a single lawful target.

4. As the experience of WWII demonstrated, recourse to "target area" bombing may cause humanitarian devastation on an unprecedented scale because of the location of lawful targets - which are not clearly separated and distinct-within an urban centre, or other residential area. However, it must be borne in mind that, under the current LOAC, all attacks are subject to the principle of proportionality and the requirement to take feasible precautions in attack. Hence, the expected collateral damage to civilians and civilian objects must not be excessive compared to the overall military advantage anticipated. ${ }^{7}$

5. Although it is not contested that this Rule is based on customary international law, some States that are not contracting parties to AP/I believe that is should be confined to circumstances in which there is an intention to terrorize the civilian population or in which the attack is expected to cause excessive collateral damage.

\footnotetext{
${ }^{7} \mathrm{AP} / \mathrm{I}$, ibid, Article 51(5)(b) and Article 57. The principle of proportionality is recited in para 1 of the Commentary to Rule 11 .
} 
6. As in other instances when the attacker is facing the risk of a breach of the principle of proportionality, the availability of precision-guided munitions (PGM) may facilitate striking lawful targets in a manner that will avoid—or, in any event, minimize - the expected collateral damage to civilians or civilian objects.

Rule 86

This Section is without prejudice to Article 56 (5) of AP/I and Article 15 of AP/II for those States Parties bound thereby. Accordingly, military objectives must not be attacked if erected for the sole purpose of protecting from attack works or installations containing dangerous forces (provided that they are not used in hostilities, except for defensive actions necessary to respond to attacks against the protected works or installations).

\section{Commentary}

1. This Rule is not restricted to military objectives by 'nature'.

2. This Rule is obligatory only for States Parties that have not made reservations concerning the provision in Article 56 (5) of AP/I and for States Parties to Article 15 of AP/II. This obligation is not considered customary international law.

3. The expression "works or installations containing dangerous forces" means dams, dikes and nuclear electrical generating stations. It does not include petrochemical works.

Open Access This chapter is licensed under the terms of the Creative Commons Attribution 4.0 International License (http://creativecommons.org/licenses/by/4.0/), which permits use, sharing, adaptation, distribution and reproduction in any medium or format, as long as you give appropriate credit to the original author(s) and the source, provide a link to the Creative Commons licence and indicate if changes were made.

The images or other third party material in this chapter are included in the chapter's Creative Commons licence, unless indicated otherwise in a credit line to the material. If material is not included in the chapter's Creative Commons licence and your intended use is not permitted by statutory regulation or exceeds the permitted use, you will need to obtain permission directly from the copyright holder.

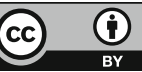

